\title{
KÖTÔDÉS, GYERMEKI ARCPREFERENCIÁK ÉS A SZEXUÁLIS IMPRINTING
}

\author{
GYURIS PETRA - KOCSOR FERENC - BERECZKEI TAMÁS \\ PTE BTK Pszichológia Intézet \\ E-mail: gyuris.petra@pte.hu
}

Beérkezett: 2016. július 19. - Elfogadva: 2017. október 28.

Háttér és célok: Az utóbbi években számos olyan kutatási beszámoló jelent meg, amely a szülók külsô megjelenésének társas vonzódásra gyakorolt hatását vizsgálták felnôttek esetében. Jelen tanulmány célja megvizsgálni e jelenséget gyerekek esetében.

Módszer: Vizsgálatunkban számítógépes program segítségével kompozit arcokat módosítottunk úgy, hogy a kisérletben részt vevoó 3 és 14 év közötti gyerekek szüleire hasonlitsanak. A képekböl tablókat készítve a gyermekeket szimpátia alapján történô választásokra kértük meg. A gyerekek szüleikkel való kapcsolatát a Düss-mese teszttel, illetve az IPPA kérdốivvel vizsgáltuk.

Eredmények: A 11-14 éves gyermekek esetében azt találtuk, hogy az anyai elidegenedés alacsony foka, azaz a jó kapcsolat növelte az anyához hasonló kortárs választásának valószínüségét. Ez különösen a fúura igaz. Az óvodás és alsó tagozatos fiúknál a szülơvel való jó kapcsolat ugyancsak fokozta annak esélyét, hogy az anyához hasonló gyermekarcot szimpatikusabbnak találják a kontrollnál. Ezzel ellentétben az ebbe a korosztályba tartozó lányoknál a jó kapcsolat csökkentette az anyához hasonló arcok választását.

Következtetések: Ezek az eredmények azt sugallják, hogy a gyermekkorban szerzett tapasztalatok hatással vannak a gyermekek arcpreferenciáira, s ezek felnöttkorra is megmaradhatnak, befolyásolva az interperszonális döntéseket. Ennek egyik megjelenési formája lehet, hogy a felnôttek különbözố szociális kapcsolataikban (például párválasztáskor) elônyben részesítik a szüleikhez hasonlító ellenkezó nemüeket. Mindennek hátterében evolúciós hatásokat sejtünk, azonban a vizsgálatunk során az egyes korcsoportok között talált különbségek arra utalnak, hogy a kognitív fejlödés sajátosságai is jelentốs szerepet játszhatnak ezeknek a preferenciáknak a kialakulásában.

Kulcsszavak: gyerekarcok, arcpreferencia, családi környezet, párválasztás, szexuális imprinting 


\section{BEVEZETÉS}

A szexuális imprinting elmélete (Bereczkei, Gyuris, Koves és Bernath, 2002; Bereczkei, Gyuris és Weisfeld, 2004) szerint a hasonlóság alapján történô párválasztás olyan bevésódés jellegú mechanizmusokra épül, amelyek a gyermekkori tapasztalatok feldolgozását irányítják. Ennek eredményeként a felnôttek azokat a partnereket részesítik elônyben hosszú távú párkapcsolataikban, akik hasonlítanak ellentétes nemú szüleikre. A gyermekek ennek a szülốnek a fenotípusát internalizálják az elsố 6-8 év során, és a késôbbiekben ezt mintegy modellként használják fel a párválasztásban.

E jelenség kialakulásának evolúciós magyarázata arra a kérdésre helyezi a hangsúlyt, hogy reproduktív szempontból milyen elónyökkel járhat, ha a partner hasonlít valamelyik szülőre. Mivel a fizikai hasonlóság hátterében jelentôs részben közös gének állnak, a szülôi modell felhasználása elôsegíti, hogy a két szülootool örökölt génállomány között nagyobb legyen az átfedés. Így a saját gének - illetve az ezekkel azonos, mások által hordozott gének - várhatóan nagyobb arányban jelennek meg az utódnemzedékben. Ez a két ok is hatással lehetett arra, hogy az evolúció során a szexuális imprinting elterjedhetett. Egyrészt a szülôk közös génjeinek nagyobb száma miatt nagyobb valószínúséggel jutnak át a következô generációba a szexuális imprinting viselkedési alapjait megteremtô gének is (Hamilton, 1964). Másrészt a több génlókuszra homozigóta utódok fenotípusa az adott ökológiai környezethez jobban alkalmazkodott változatot képviselhet (Read és Harvey, 1988). Ez ellensúlyozhatja a beltenyészet miatti esetleges genetikai leromlást (Blouin és Blouin, 1988; Potts, Manning és Wakeland, 1991). Öszszességében tehát a szülői modell alkalmazása optimális genetikai távolságot eredményezhet a párok között (Bateson, 1983).

A szelekciós elônyök ismeretében nem meglepó, hogy számos kutatási adat támasztja alá, hogy a szülốk külsố tulajdonságai befolyásolják felnốtt gyerekeik párválasztási preferenciáját. Az életkorral kapcsolatban például kimutatták, hogy azok a felnôttek, akiknek ellentétes nemú szülóje idôsebb, jobban vonzódnak a magasabb életkorra utaló arcvonásokkal rendelkezô partnerekhez, mint azok, akiknek szülei fiatalabbak (Perrett és mtsai, 2002; Heffernan és Fraley, 2013; Wilson és Barrett, 1987; Zei, Astofli és Jaykar, 1981). A szemszín, hajszín és etnikai hovatartozás tekintetében a partner és a szülô között jelentôs hasonlóságot találtak (Jedlicka, 1980, 1984; Little, Penton-Voak, Burt és Perrett, 2002; Wilson és Barrett 1987; Saxton, 2016). A szülôi jellegek az arcon kívül esô tulajdonságok, például a testszôrzet (Rantala, Pölkki és Rantala, 2009) és a magasság iránti preferenciára is hatással vannak (Seki és mtsai, 2012). Egy újabb vizsgálatban azt is kimutatták, hogy a kísérleti személyek szexuálisan vonzóbbnak találták azokat az ellentétes nemú arcokat, amelyek elôtt az ellentétes nemú szülô arca szubliminálisan jelent meg (Fraley és Marks, 2010). Ez arra utalhat, hogy egy-egy testi jellemzô vonzerejéhez az is hozzájárulhat, ha az kapcsolódik valamelyik szülőhöz, azaz hasonlóság áll fenn.

Számos olyan tanulmány látott már napvilágot, amelyben számítógépes technikákat felhasználva kompozit arcokat tettek fiatal felnôttek ellentétes nemú szüleihez hasonlóvá, s így vizsgálták annak rövid, illetve hosszú távú kapcsolatra gyakorolt hatását. A vizsgálatok egy része azt találta, hogy a fiatal felnôttek elônyben részesítik a szüleikhez hasonló potenciális partnereket (Kocsor, Saxton, Láng és Bereczkei, 2016), míg mások nem találtak ilyen összefüggést (Nojo, Ihara, Furusawa, Akamatsu és Ishida, 
2011; Sulutvedt és Laeng, 2014). Más vizsgálatokból kiderült, hogy az arc középsô területén hasonlóság mutatkozik a nôi kísérleti személyek apja és az általuk vonzónak ítélt férfi között - azaz a férfi és apósa között -, az arc alsó régiójában pedig a nô és anyósa között van nagyfokú hasonlóság (Wiszewska, Pawlowski és Boothroyd, 2007). Egy újabb vizsgálatban azt találták, hogy a feleség és az anya, továbbá a férj és az apa hasonlít egymásra bizonyos arcmetrikai jellegzetességekben (Nojo és mtsai, 2011).

Néhány kutatás arra is rávilágított, hogy pozitív összefüggés van a szülőéhez hasonló arc iránti vonzódás és a szülóvel való gyerekkori kapcsolat között (Bereczkei és mtsai, 2002; Bereczkei és mtsai, 2004; Watkins és mtsai, 2011; Wiszewska és mtsai, 2007). Ez még akkor is így van, ha a szülők örökbefogadott gyereket neveltek, azaz nem volt köztük biológiai rokonság, így kizárható volt a genetikailag közvetített hasonlóság (Bereczkei és mtsai, 2004). A kísérletek alapján úgy túnik, hogy a gyermekkorban tapasztalt érzelmi melegség, illetve a kisebb mértékú visszautasítás megnöveli annak valószínúségét, hogy - elsôsorban az ellentétes nemú - szülô arcvonásait vagy egyéb jellemzóit (pl. szemszín, lásd Saxton, 2016) a felnôttek vonzónak tartsák. Ezek alapján a szülôi kapcsolat az ilyen jellegú arcpreferenciák fontos közvetítô tényezôjének tûnik. Ugyanakkor ezt a feltételezést nem mindegyik kísérletnek sikerült igazolnia (Marcinkowska és Rantala, 2012; Nojo, Tamura és Ihara, 2012).

Az eddigi kutatások azt vizsgálták, hogy a felnôttek milyen részrehajlást mutatnak a családtagjaik arcvonásait tükrözô ismeretlen személyek iránt, illetve felnôttként menynyire használják fel a gyerekkori tapasztalataikat a párválasztásban (Kocsor és mtsai, 2016; Saxton, 2016). Arra azonban kevés figyelmet fordítottak, hogy milyen fejlôdési útvonalon keresztül alakul ki ez az arcpreferencia. A csekély számú eddigi vizsgálat egyikében 9 éves gyerekeket kérdeztek meg arról, mennyire tartják vonzónak a nekik bemutatott, felnôtteket ábrázoló arcképeket (Vukovic, Boothroyd, Meins és Burt, 2015). Azok a gyerekek, akik elfogadóbbak voltak szüleikkel és kevésbé voltak elutasítóak velük, nagyobb valószínúséggel választották a szüleikhez hasonló manipulált képeket. Egy másik kísérlet során retrospektív szülối kérdôívekre adott válaszok és a szülők, valamint az aktuális, illetve az ideális partner szemszíne és hajszíne között találtak kapcsolatot (Saxton, 2016). Azaz a szülókkel való jó kapcsolat befolyásolta a szülôk szem és hajszíne alapján való partnerválasztásukat mind az ideális, mind az aktuális partner esetében.

Mivel a gyerekeknek általában több tapasztalatuk van a korban hozzájuk közel állókkal, mint felnôttekkel, gyerekarcokban várhatóan jobban felismerik az ismerôs arcvonásokat, mint idôsebb arcképekben (Kaminski, Gentaz és Mazens, 2011). E mellett szól az is, hogy a Richter, Tiddeman és Haun (2012) kísérletében részt vevô kisiskolás fiúk nem csupán felismerték azokat az arcokat, amelyeket úgy manipuláltak, hogy hasonlítsanak hozzájuk, hanem szívesebben is kötöttek volna barátságot ezekkel a gyerekekkel. Ez összhangban van a szülôi imprinting elméletének tesztelését célul kitûzô, korábban említett vizsgálatokkal. Eddig azonban azt nem vizsgálták, hogy a gyerekek a társas kapcsolataikban felhasználják-e a szülői modelleket. Ennek egyik megjelenési formája az lehet, ha a gyerekek nagyobb hajlandóságot mutatnak a szülókre hasonlító gyerekekkel való barátkozásra. Nyitott kérdés az is, hogy vajon ez a részrehajlás valóban függ-e a szülókkel való kapcsolattól, mint azt a szexuális imprinting elmélete alapján várhatjuk. 
A fentiek alapján a következó hipotéziseket fogalmaztuk meg:

1. A gyerekek társas kapcsolataikban előnyben részesítik a szüleikre hasonlító gyermekarcokat más, idegen felnôttre hasonlító gyerekarcokkal szemben.

2. A gyerekek arcpreferenciáját befolyásolja szüleikkel való kapcsolatuk, azaz a szüleikkel jobb kapcsolatban lévő gyerekek nagyobb valószínúséggel választják a szüleikre hasonlító gyermekarcokat a szüleikkel kevésbé jó kapcsolatban lévô gyerekekhez képest.

\section{MÓDSZEREK}

\section{Vizsgálati személyek}

Vizsgálatunkban összesen 191, 3 és 14 év közötti gyerek, valamint azok szülei vettek részt (1. táblázat). (A kutatás EPKEB engedélyének száma: 2010/14.) Az óvodás korosztály tagjai azonosak a Kocsor, Gyuris és Bereczkei (2013) által vizsgált mintával.

1. táblázat. Kísérleti személyek száma és életkori adatai

\begin{tabular}{|c|c|c|c|c|c|c|}
\hline \multirow[t]{2}{*}{ Csoport } & \multirow{2}{*}{$\begin{array}{c}\text { fó } \\
\text { (gyerek) }\end{array}$} & \multirow[t]{2}{*}{ nem és fố } & \multicolumn{4}{|c|}{ Életkor (év/hó) } \\
\hline & & & minimum & maximum & átlag & szórás \\
\hline \multirow{2}{*}{$\begin{array}{l}\text { 1. csoport } \\
\text { (óvodások) }\end{array}$} & \multirow[t]{2}{*}{87} & fiú: 47 & 3 & $6 / 11$ & 5,47 & 1,01 \\
\hline & & lány: 40 & $3 / 5$ & $6 / 10$ & 5,32 & 1,06 \\
\hline \multirow{2}{*}{$\begin{array}{l}\text { 2. csoport } \\
\text { (alsó tagozatosok) }\end{array}$} & \multirow[t]{2}{*}{63} & fiú: 29 & $6 / 1$ & $10 / 11$ & 8,81 & 1,32 \\
\hline & & lány: 34 & 7 & $10 / 11$ & 8,98 & 1,25 \\
\hline \multirow{2}{*}{$\begin{array}{l}\text { 3. csoport } \\
\text { (felsố tagozatosok) }\end{array}$} & \multirow[t]{2}{*}{41} & fiú: 26 & $11 / 1$ & $14 / 11$ & 12,98 & 1,15 \\
\hline & & lány: 15 & $10 / 9$ & $14 / 6$ & 12,76 & 1,14 \\
\hline
\end{tabular}

\section{Ingeranyag}

A vizsgálati személyek szüleirôl fényképeket készítettünk standardizált körülmények között. A felnôtt egyéni arcokat 50\%-ban transzformáltuk (morfoltuk) a korosztálynak megfelelő átlagolt azonos nemú gyerekarcokba. Az átlagolt azonos nemú arcokat mindegyik esetben 8 darab, a korosztálynak megfelelő egyéni arcból hoztuk létre Pychoí-morph programmal (Tiddeman, Burt és Perrett, 2001; Tiddeman, Stirrat és Perrett, 2005) (lásd 1. ábra).

A morfolt arcokból tablókat készítettünk a Gimp 2 képszerkesztô szoftver használatával (2. ábra). Egy tabló mérete 950×600 volt, két morfolt arckép szerepelt rajta. Egy vizsgálati személy tesztjéhez két tabló tartozott két-két képpel: az egyik tablón az anya (a vizsgálati személy saját anyja) és egy kontrollanya (más gyerek anyja), a másik tablón az apa (a vizsgálati személy saját apja) és egy kontrollapa (másik gyerek apja) fényképét is tartalmazó - a gyerek nemének és korosztályának megfelelố - átlaggyerekarc volt látható. A vizsgálati helyzetben a két tabló megjelenési sorrendjét, valamint a tablókon a két kép helyzetét is (bal vagy jobb oldal) DmDX programmal randomizáltuk és jelenítettük meg egy laptop képernyôjén. 

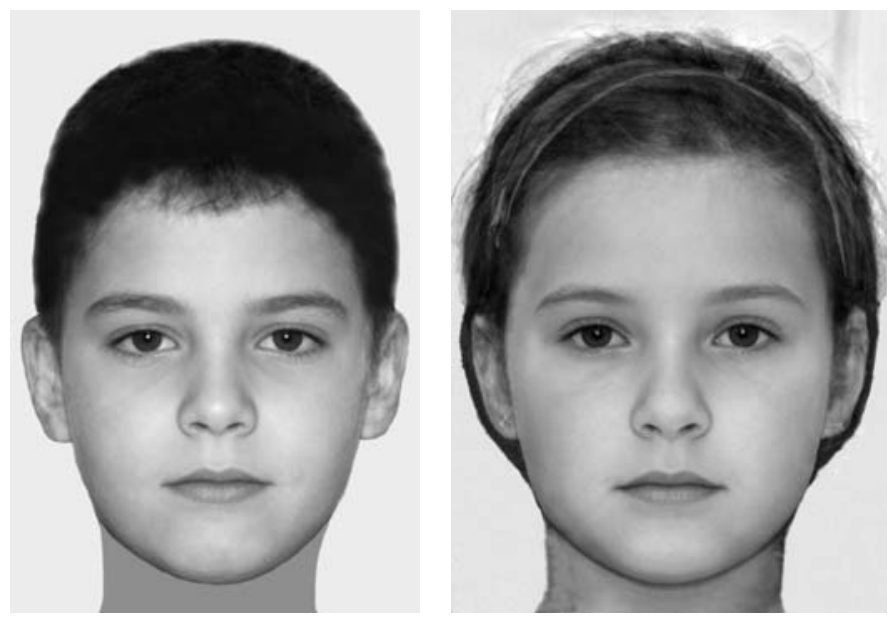

1.ábra. Alsó tagozatos átlagarcok
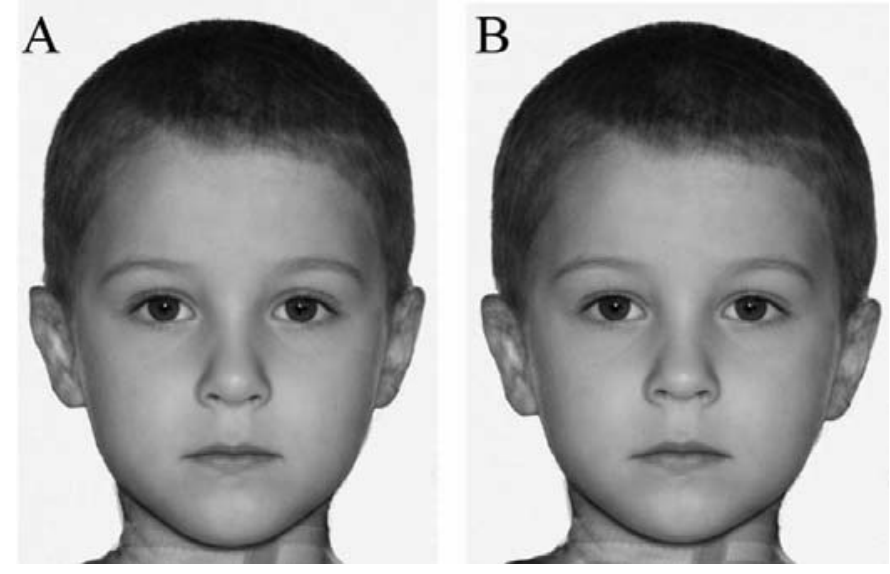

2. ábra. Példa óvodás fiúknak bemutatott tablóra:

a vizsgálati személy anyjára (A) és egy kontrollanyára (B) hasonlító arcképek

\section{Kérdôivek}

A szülőkkel való kapcsolat vizsgálatára az elsố két csoportnál, azaz az óvodásoknál és alsó tagozatos gyereknél a Düss-meseteszt elsố meséjét, az úgynevezett madármesét alkalmaztuk. A Düss-mesék a gyermekanalízis és terápia hatékony diagnosztikus eszközei közé tartoznak. E mesék hatékonyan használják fel az állatokkal való azonosulás gyermekkori tendenciáit a tudattalan vágyak, szorongások, konfliktusok feltárására (Kôvári és Látos, 2010). Pszichológiai múködésük abban rejlik, hogy a kísérletvezetô vagy pszichológus csupán elkezdi a történetet, és a gyermek fejezi be. A gyerek ez alatt olyan szituációba éli bele magát, amely a tudattalan fejlôdésének egy állapotát mutat- 
ja be, és korlátlan lehetôsége van a mese befejezésére (Reynolds és Kamphaus, 2003). A történet befejezésébôl pedig számos pszichológiai mechanizmusra, a madármese esetében például a szülôk hozzáférhetôségére, indirekt módon pedig a hozzájuk való kötốdés biztonságosságára is következtetni lehet (pl. az elsố mese esetében a fészekbôl a szülei mellôl a földre leesett madárfióka odarepül-e valamelyik szülóhöz, akik a vihart követốen más-más fára szálltak) (Mazzeschi, Lis, Calvo, Vallone és Superchi, 2001). A meseteszt eredetileg nem tartalmaz képet, de a könnyebb beleélhetôség kedvéért készíttettünk fiúk és lányok részére kettô-kettô rajzképet a történethez (3. és 4. ábra).

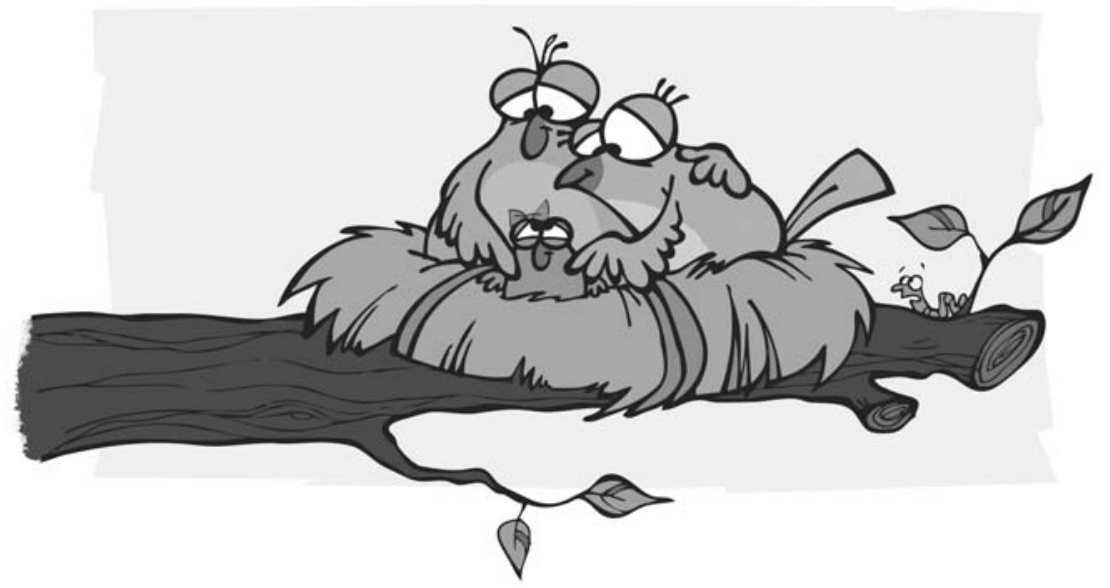

3. ábra. A madármeséhez készített illusztráció lányoknak

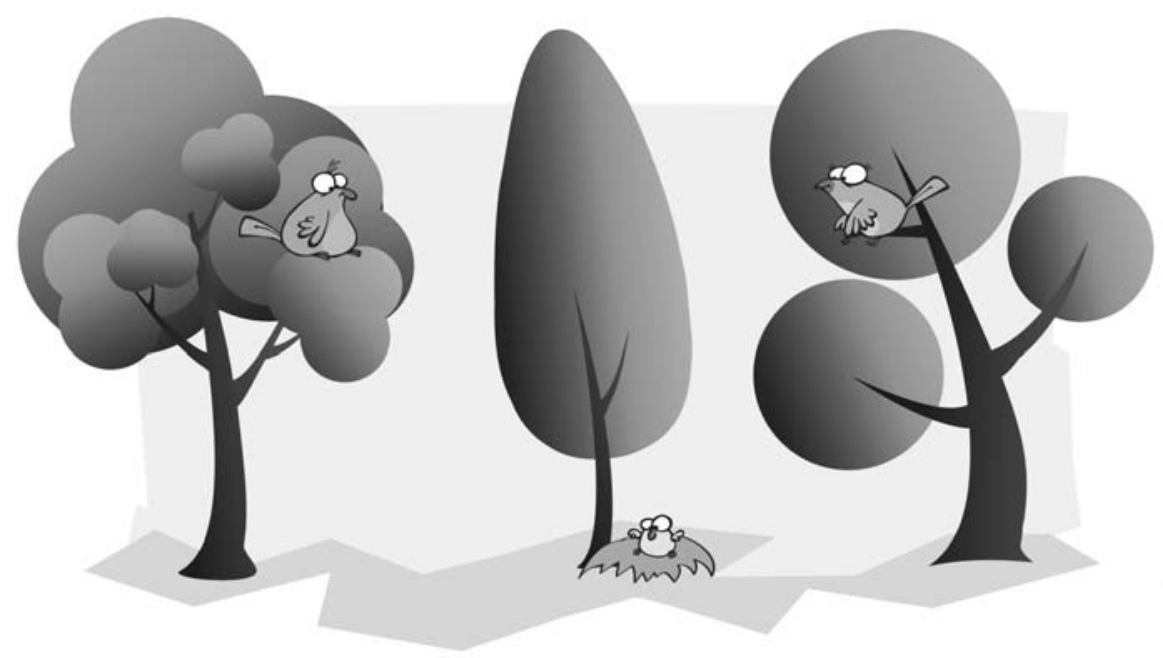

4. ábra. A madármeséhez készített illusztráció fiúknak 
A kötôdés mérésére a 3. csoportnál, azaz a 10-14 éves, felsô tagozatos gyerekeknél az Inventory of Parent and Peer Attachment (IPPA) önkitöltôs teszt magyar nyelvú változatát használtuk. Ez a teszt 3 alskálája segítségével a serdülók kötôdését vizsgálja (Armsden és Greenberg, 1987). A bizalom a kölcsönös megértést méri olyan állításokra adandó válaszok segítségével, mint például „Anyukám elfogad engem olyannak, amilyen vagyok.” A kommunikáció alskála a szóbeli kommunikáció minôségét és mértékét teszteli, például: „Meg tudom beszélni anyukámmal, ha valami feldühít.” Az elidegenedés alskála a harag érzéseit és az interperszonális elidegenedést vizsgálja: „Anyukám nem érti, hogy min megyek keresztül mostanában.” A kötôdés a három alskála alapján kerül meghatározásra: a bizalom és a kommunikáció pontszámaihoz az elidegenedés fordított pontjait adva kapjuk meg a kötôdés mértékét. Minél magasabb értéket kapunk, a kötôdés annál biztonságosabbnak tekinthetô. Az elidegenedés faktor negatívan korrelál a bizalom és a kommunikáció faktorral, így az elidegenedésre adott alacsony pontszám a jobb kapcsolatot jelzi.

\section{A vizsgálat menete}

A tesztek felvétele minden esetben nyugodt, csendes körülmények között, a szülők jelenléte nélkül, azonos forgatókönyv alapján történt. A spontán, barátkozó beszélgetés után a vizsgálatvezetô a gyerek mellett úgy helyezkedett el, hogy a gyerek ne lássa arcát. A vizsgálatvezetô a tablókat a számítógép monitorján randomizált sorrendben mutatta be. Minden egyes tabló esetében a gyerekek a következô szimpátiaválasztáson alapuló kérdést kapták: „Most gyerekekról készült fényképeket mutatok neked. Az óvodai csoportodba / iskolai osztályodba ez a két új gyerek érkezik, Te melyikükkel játszanál szívesebben? Mutasd meg!" A gyermek válaszát a vizsgálatvezetô rögzítette a laptop megfelelô billentyújének lenyomásával. Ezt követôen a vizsgálatvezetô felolvasta és képekkel illusztrálta a Düss-mese elsô, ún. madármeséjét. A gyermek válaszát papíron rögzítettük.

Az elsô két korcsoportnál (3-6 éves óvodás és 7-10 éves alsó tagozatos gyerekek) a Düss-mesében adott válaszaik, tehát az alapján, hogy a leesett madárfióka hova repül, több alcsoportot képeztünk: 1 . anyát választók (a fióka az anyjához repül), 2. apát választók (a fióka az apához repül), 3. egyik szülōt sem választók (a fióka például a földön marad).

A felsố tagozatos iskolás gyerek a tablókra adott válaszaikat követôen papír-ceruza módszerrel töltötték ki az IPPA önkitöltős tesztet.

\section{EREDMÉNYEK}

\section{Hasonlóság hatása az arcpreferenciákra}

Adatainkat az SPSS 22 statisztikai program segítségével elemeztük. Az elsô, a szülôi arc preferenciájára vonatkozó hipotézisünket egymintás khi-négyzet próbával teszteltük, a nemek összehasonlítására pedig független mintás khi-négyzet próbát használtunk. Az elemzéseket mindkét esetben a válaszok gyakorisági adatain végeztük, azaz azt ha- 
sonlítottuk össze, hogy a gyerekek hányszor választották a szüleikre hasonlító arcképet és a kontrollarcképet. Sem az anyai $\left(\chi^{2}=0,526 ; p=0,468\right)$, sem az apai arcokra nem találtunk szignifikáns különbséget a kontrollhoz képest $\left.\chi^{2}=0,189 ; p=0,663\right)$. Tehát a 3-14 éves gyerekek nem preferálták jobban a szüleikre hasonlító gyerekarcokat más, idegen arcokkal szemben. A fiúk és a lányok választása között sem találtunk különbséget $\left(\chi^{2}=0,114 ; p=0,736\right)$.

Mivel a korábbi kutatások (Saxton, 2016) azt mutatják, hogy az életkor hatással lehet az arcpreferenciákra, ezért generalizált lineáris kevert modell (GLMM) segítségével elemeztük, hogy az arcok közötti választásra hatással van-e, hogy a gyerek melyik korcsoportba tartozik. További változóként a gyerek nemét és a korcsoport és nem közötti interakciót vontuk be az elemzésbe. A bináris logisztikus modellek célváltozója az anyai/kontroll arc, illetve az apai/kontroll arc választása volt. Random változóként - akárcsak az ezt követô összes GLMM modellnél - a mintagyújtésben részt vevô személy azonosítóját is a modellbe építettük. A modell egyik tablónál sem volt szignifikáns, és a rögzített változók közül egyik sem volt szignifikáns hatással a képek közötti választásra (2-3. táblázat).

2. táblázat. Az 1. GLMM modell prediktor változói és statisztikai adatai (bináris logisztikus modell, célváltozó az anyai/kontroll arc választása)

\begin{tabular}{|c|c|c|c|c|c|c|}
\hline \multirow{3}{*}{ A modell illeszkedése } & \multirow{3}{*}{$\begin{array}{l}\text { Akaike-kritérium } \\
\text { Pontosság }\end{array}$} & \multirow{3}{*}{$\begin{array}{l}813,343 \\
57,4 \%\end{array}$} & \multirow[t]{3}{*}{$\boldsymbol{F}$} & \multirow[t]{3}{*}{$s z f 1$} & \multirow[t]{3}{*}{$s z f 2$} & \multirow[t]{3}{*}{$p$} \\
\hline & & & & & & \\
\hline & & & & & & \\
\hline \multirow{4}{*}{ Rögzített hatások } & Korrigált modell & & 1,378 & 5 & 184 & 0,235 \\
\hline & Korcsoport & & 1,358 & 2 & 184 & 0,260 \\
\hline & Nem & & 0,003 & 1 & 184 & 0,958 \\
\hline & Korcsoport*nem & & 1,692 & 2 & 184 & 0,187 \\
\hline
\end{tabular}

3. táblázat. A 2. GLMM modell prediktor változói és statisztikai adatai (bináris logisztikus modell, célváltozó az apai/kontroll arc választása)

\begin{tabular}{lllllll} 
& & & $\boldsymbol{F}$ & $\boldsymbol{s z f 1}$ & $\boldsymbol{s z f 2}$ & $\boldsymbol{p}$ \\
\cline { 6 - 7 } A modell illeszkedése & Akaike-kritérium & 811,932 & & & & \\
& Pontosság & $57,4 \%$ & & & & \\
\multirow{2}{*}{ Rögzített hatások } & Korrigált modell & & 1,218 & 5 & 184 & 0,302 \\
& Korcsoport & & 2,053 & 2 & 184 & 0,131 \\
& Nem & & 2,251 & 1 & 184 & 0,135 \\
& Korcsoport*nem & & 0,136 & 2 & 184 & 0,873 \\
\hline
\end{tabular}

\section{Szülôvel való kapcsolat hatása az arcpreferenciákra - elsô elemzés}

Második hipotézisünk ellenôrzésére, azaz annak eldöntésére, hogy a gyerekek szüleikkel való kapcsolata befolyásolja-e az arcokkal kapcsolatos preferenciájukat, szintén GLMM modellt használtunk. A szülőkkel való kapcsolat vizsgálatának eltérô módszere 
miatt az óvodás és az alsós gyerekek adatait együtt elemeztük, a felsôsök adatait külön kezeltük.

Mivel a mintánkban szereplố legtöbb 3-10 éves gyerek fóleg az anyát nevezte meg a madármesében (110 fô), és nagyon kevesen voltak (15 fö), akik az apát választották, ezért egy újabb változót hoztunk létre két lehetséges értékkel: a madármesére adott válaszaik alapján valamelyik szülốt választó, illetve egyik szülốt sem választó gyerekek.

A modellbe rögzített változóként a vizsgálati személyek neme (fiú, lány), korcsoportja (óvodás, alsós), a szülốvel való kapcsolat (szülốt választó, szüloót nem választó), valamint az ezek közötti kettôs interakciók kerültek. Az elsố tablónál (anya/kontroll) kapott modell nem volt szignifikáns (4. táblázat), az Akaike-kritérium magas értéke szintén a változók gyenge prediktív erejét jelzi. A rögzített változók közül egyik sem volt szignifikáns hatással a képek közötti választásra, csupán a vizsgálati személyek neme mutatott tendenciaszintú hatást. A GLMM elemzésen belül az adatok páronkénti összehasonlítása - melynek során szekvenciális Bonferroni-korrekciót alkalmaztunk - azt mutatta, hogy a mesetesztben valamelyik szülốt választó gyerekek közül a lányok szignifikánsan nagyobb valószínúséggel választják a kontrollszemélyhez hasonló arcot az anyához hasonlóhoz képest, mint a fiúk $(t=2,130, s z f=138 p=0,035)$.

4. táblázat. A 3. GLMM modell prediktor változói és statisztikai adatai (bináris logisztikus modell, célváltozó az anyai/kontroll arc választása)

\begin{tabular}{|c|c|c|c|c|c|c|}
\hline \multirow{3}{*}{ A modell illeszkedése } & \multirow{3}{*}{$\begin{array}{l}\text { Akaike-kritérium } \\
\text { Pontosság }\end{array}$} & \multirow{3}{*}{$\begin{array}{l}620,403 \\
70,3 \%\end{array}$} & \multirow[t]{3}{*}{$\boldsymbol{F}$} & \multirow[t]{3}{*}{$s z f 1$} & \multirow[t]{3}{*}{$s z f 2$} & \multirow[t]{3}{*}{$p$} \\
\hline & & & & & & \\
\hline & & & & & & \\
\hline \multirow{7}{*}{ Rögzített hatások } & Korrigált modell & & 1,040 & 6 & 138 & 0,402 \\
\hline & Korcsoport & & 0,346 & 1 & 138 & 0,557 \\
\hline & Nem & & 3,147 & 1 & 138 & 0,078 \\
\hline & Kapcsolat & & 1,748 & 1 & 138 & 0,188 \\
\hline & Korcsoport*nem & & 0,226 & 1 & 138 & 0,635 \\
\hline & Kapcsolat*nem & & 1,707 & 1 & 138 & 0,194 \\
\hline & Korcsoport*kapcsolat & & 0,206 & 1 & 138 & 0,650 \\
\hline
\end{tabular}

A második tabló esetében szignifikáns modellt kaptunk (5. táblázat), melynek magas Akaike-kritérium értéke a változók és képek közötti választás közti gyenge kapcsolatra utal. A rögzített változók közül a korcsoport (óvodás, alsós) tendenciaszerú, míg a szülôkkel való kapcsolat szignifikáns hatással volt a választásra. A páronkénti összehasonlítások azt az eredményt hozták, hogy a mesetesztben szülőket nem választó gyerekek nagyobb valószínúséggel választották a kontrollarcot, mint a szülôket választó gyerekek $(t=2,365, s z f=138, p=0,019)$, ez a különbség pedig külön a fiúk esetében is szignifikáns $(t=2,281, s z f=138, p=0,024)$. A szülooket nem választókon belül az óvodások az alsósokhoz képest a kontrollt szignifikánsan nagyobb valószínúséggel választották $(t=-2,278, s z f=138, p=0,024)$, az óvodásokon belül pedig a szülôket nem választók szintén szignifikánsan különböztek a szülőket választóktól $(t=$ 2,776, szf $=138, p=0,006)$. 
5. táblázat. A 4. GLMM modell prediktor változói és statisztikai adatai (bináris logisztikus modell, célváltozó az apai/kontroll arc választása)

\begin{tabular}{|c|c|c|c|c|c|c|}
\hline \multirow{3}{*}{ A modell illeszkedése } & \multirow{3}{*}{$\begin{array}{l}\text { Akaike-kritérium } \\
\text { Pontosság }\end{array}$} & \multirow{3}{*}{$\begin{array}{l}627,539 \\
74,5 \%\end{array}$} & \multirow[t]{3}{*}{$\boldsymbol{F}$} & \multirow[t]{3}{*}{$s z f 1$} & \multirow[t]{3}{*}{$s z f 2$} & \multirow[t]{3}{*}{$p$} \\
\hline & & & & & & \\
\hline & & & & & & \\
\hline \multirow{7}{*}{ Rögzített hatások } & Korrigált modell & & 2,209 & 6 & 138 & 0,046 \\
\hline & Korcsoport & & 3,035 & 1 & 138 & 0,084 \\
\hline & Nem & & 2,320 & 1 & 138 & 0,130 \\
\hline & Kapcsolat & & 5,246 & 1 & 138 & 0,024 \\
\hline & Korcsoport*nem & & 0,226 & 1 & 138 & 0,635 \\
\hline & Kapcsolat*nem & & 0,418 & 1 & 138 & 0,519 \\
\hline & Korcsoport*kapcsolat & & 1,377 & 1 & 138 & 0,243 \\
\hline
\end{tabular}

A 3. csoport (felsố tagozatos, 11-14 éves gyerekek) adatainak elemzésekor a GLMM modellbe rögzített változóként a vizsgálati személyek neme (fiú, lány) és a vizsgált tabló szempontjából releváns szülőhöz tartozó három IPPA-alskála pontszáma került, valamint a nem és az IPPA-pontszámok közötti kettôs interakciók. Az elsô tablónál (anya/kontroll) kapott modell nem volt szignifikáns (6. táblázat). A rögzített változók közül az anyai bizalom volt szignifikáns hatással a képek közötti választásra; magasabb pontszám az anyai bizalom alskálán jobban valószínúsíti az anyai arc választását. Nem volt szignifikáns a második tablónál (apa/kontroll) kapott modell sem (7. táblázat). A rögzített változók között nem találtunk olyat, amely szignifikáns hatással lett volna a képek közötti választásra, csupán a gyerek nemének van tendenciaszerú hatása. Ez arra utal, hogy a felsôs fiúk nagyobb valószínúséggel választják a kontroll arcot az apai archoz képest, mint a lányok.

6. táblázat. Az 5. GLMM modell prediktor változói és statisztikai adatai (bináris logisztikus modell, célváltozó az anyai/kontroll arc választása)

\begin{tabular}{|c|c|c|c|c|c|c|}
\hline \multirow{3}{*}{ A modell illeszkedése } & \multirow{3}{*}{$\begin{array}{l}\text { Akaike-kritérium } \\
\text { Pontosság }\end{array}$} & \multirow{3}{*}{$\begin{array}{l}242,538 \\
83,7 \%\end{array}$} & \multirow[t]{2}{*}{$\boldsymbol{F}$} & \multirow[t]{2}{*}{$s z f 1$} & \multirow[t]{2}{*}{$s z f 2$} & \multirow[t]{2}{*}{$p$} \\
\hline & & & & & & \\
\hline & & & & & & \\
\hline \multirow{8}{*}{ Rögzített hatások } & Korrigált modell & & 1,199 & 7 & 41 & 0,325 \\
\hline & Nem & & 1,685 & 1 & 41 & 0,202 \\
\hline & IPPA anyai bizalom & & 3,749 & 1 & 41 & 0,060 \\
\hline & IPPA anyai kommunikáció & & 4,072 & 1 & 41 & 0,050 \\
\hline & IPPA anyai elidegenedés & & 0,469 & 1 & 41 & 0,498 \\
\hline & IPPA anyai bizalom*nem & & 0,009 & 1 & 41 & 0,923 \\
\hline & $\begin{array}{l}\text { IPPA anyai } \\
\text { kommunikáció*nem }\end{array}$ & & 0,091 & 1 & 41 & 0,764 \\
\hline & $\begin{array}{l}\text { IPPA anyai } \\
\text { elidegenedés*nem }\end{array}$ & & 1,749 & 1 & 41 & 0,193 \\
\hline
\end{tabular}


7. táblázat. A 6. GLMM modell prediktor változói és statisztikai adatai (bináris logisztikus modell, célváltozó az apai/kontroll arc választása)

\begin{tabular}{|c|c|c|c|c|c|c|}
\hline \multirow{3}{*}{ A modell illeszkedése } & \multirow{3}{*}{$\begin{array}{l}\text { Akaike-kritérium } \\
\text { Pontosság }\end{array}$} & \multirow{3}{*}{$\begin{array}{l}234,089 \\
80,0 \%\end{array}$} & \multirow[t]{3}{*}{$\boldsymbol{F}$} & \multirow[t]{3}{*}{$s z f 1$} & \multirow[t]{3}{*}{$s z f 2$} & \multirow[t]{3}{*}{$p$} \\
\hline & & & & & & \\
\hline & & & & & & \\
\hline \multirow{8}{*}{ Rögzített hatások } & Korrigált modell & & 0,736 & 7 & 42 & 0,643 \\
\hline & Nem & & 3,374 & 1 & 42 & 0,073 \\
\hline & IPPA apai bizalom & & 0,825 & 1 & 42 & 0,369 \\
\hline & IPPA apai kommunikáció & & 0,426 & 1 & 42 & 0,517 \\
\hline & IPPA apai elidegenedés & & 0,779 & 1 & 42 & 0,383 \\
\hline & IPPA apai bizalom*nem & & 2,284 & 1 & 42 & 0,138 \\
\hline & $\begin{array}{l}\text { IPPA apai } \\
\text { kommunikáció*nem }\end{array}$ & & 1,192 & 1 & 42 & 0,281 \\
\hline & $\begin{array}{l}\text { IPPA apai } \\
\text { elidegenedés*nem }\end{array}$ & & 0,231 & 1 & 42 & 0,634 \\
\hline
\end{tabular}

\section{Szülốvel való kapcsolat hatása az arcpreferenciákra - második elemzés}

A szülőkkel való kapcsolat és az arcpreferencia közti kapcsolatot megkíséreltük más statisztikai megközelítésben is vizsgálni. Független mintás t-próbával összehasonlítottuk, hogy azoknak az IPPA pontszámai, akik szimpatikusabbnak tartják a valamely szülôjükhöz hasonló arcokat, eltérnek-e azokétól, akik a kontrollarcot választják. Az elsô tablónál mindkét nemet vizsgálva azt találtuk, hogy azok, akik az anyához hasonló arcot választották, szignifikánsan magasabb pontszámot értek el az anyai elidegenedés alskálán, mint a kontrollarcot választók (8. táblázat). A két nem adatait külön elemezve kiderült, hogy az elôbbi eredmény elsôsorban a fiúk válaszainak köszönhetô, mivel a nemenkénti elemzésnél a fiúknál szignifikáns különbséget kaptunk, a lányoknál pedig nem. A fiúknál az előbbihez hasonló irányú, nem szignifikáns tendenciát találtunk az anyai bizalom alskálára vonatkozóan. A magasabb pontszám mindkét faktornál jobb

8. táblázat. Az IPPA alskálain lefuttatott független mintás $t$-próba statisztikai adatai.

Csoportosító változóként az 1. tablónál adott válaszokat használtuk (anyai/kontroll arc)

\begin{tabular}{llcccc} 
& & Átlagos eltérés & $\boldsymbol{t}$ & $\boldsymbol{s z f}$ & $\boldsymbol{p}$ \\
\cline { 2 - 5 } Anyai bizalom & Teljes minta & 2,096 & 1,585 & 49 & 0,119 \\
& Fiúk & 3,138 & 1,982 & 29 & $\mathbf{0 , 0 5 7}$ \\
& Lányok & 0,583 & 0,246 & 18 & 0,809 \\
\hline \multirow{3}{*}{ Anyai kommunikáción } & Teljes minta & $-0,808$ & $-0,484$ & 49 & 0,630 \\
& Fiúk & 1,850 & 0,913 & 29 & 0,369 \\
& Lányok & $-4,471$ & $-1,637$ & 19 & 0,118 \\
\hline \multirow{3}{*}{ Anyai elidegenedés } & Teljes minta & 2,622 & 2,183 & 47 & $\mathbf{0 , 0 3 4}$ \\
& Fiúk & 4,200 & 2,911 & 29 & $\mathbf{0 , 0 0 7}$ \\
& Lányok & 0,409 & 0,196 & 17 & 0,847 \\
\hline
\end{tabular}

*Eredmények szignifikánsak p $<0,05$-ös szignifikanciaszinten 
kapcsolatot jelez. A második tablónál (apa/kontroll) semmilyen szignifikáns eredményt nem kaptunk (9. táblázat).

9. táblázat. Az IPPA alskálain lefuttatott független mintás $t$-próba statisztikai adatai. Csoportosító változóként az 1. tablónál adott válaszokat használtuk (anyai/kontroll arc)

\begin{tabular}{llcccc} 
& & Átlagos eltérés & $\boldsymbol{t}$ & $\boldsymbol{s z f}$ & $\boldsymbol{p}$ \\
\cline { 3 - 6 } Anyai bizalom & Teljes minta & 0,451 & 0,351 & 48 & 0,727 \\
& Fiúk & 2,330 & 1,564 & 28 & 0,129 \\
& Lányok & $-2,536$ & $-1,168$ & 19 & 0,809 \\
\hline \multirow{3}{*}{ Anyai kommunikáción } & Teljes minta & $-0,539$ & $-0,290$ & 48 & 0,773 \\
& Fiúk & 0,439 & 0,208 & 28 & 0,837 \\
& Lányok & $-2,709$ & $-0,804$ & 19 & 0,118 \\
\hline \multirow{3}{*}{ Anyai elidegenedés } & Teljes minta & $-0,251$ & $-0,229$ & 48 & 0,820 \\
& Fiúk & 0,855 & 0,578 & 28 & 0,568 \\
& Lányok & $-2,209$ & $-1,471$ & 19 & 0,847 \\
\hline
\end{tabular}

\section{MEGVITATÁS}

\section{Hasonlóság hatása az arcpreferenciákra}

Elsố hipotézisünket nem tudtuk igazolni, azaz a 3 és 14 év közötti gyerekek egyszerú választás esetén nem részesítik elônyben a szüleikre hasonlító arcokat az idegenekhez képest.

Ez nagyon meglepó eredmény, hiszen szinte valamennyi pszichológiai tanulmány és könyv kiemeli, hogy ez az idôszak kulcsfontosságú a gyerek szülôvel való identifikációja szempontjából (Cassidy és Shaver, 1999). Elképzelhető, hogy ennél a korosztálynál még nem alakultak ki vagy nem elég érettek azok a kognitív folyamatok, amelyek lehetôvé teszik, hogy a szülőii arc sajátosságait egy idegen arcban is felismerjék. Lehetséges, hogy még gyengén múködnek azok a finom differenciálást lehetôvé tévô detektálási folyamatok, amelyek a szülôi jellegeket viselô átlagarcot meg tudnák különböztetni az ismeretlen felnôtt arcvonásait tartalmazó átlagarctól. Ez felnôttek számára sem egyszerú feladat: több vizsgálat is azt mutatja, hogy a kísérleti személyek ugyan elônyben részesítik saját magukat vagy rokonaikat a morfolt képeken, de nem tudják felismerni és azonosítani ezeket az arcokat (DeBruine, Jones, Little és Perrett, 2008; Kocsor és mtsai, 2011; Kocsor és mtsai, 2016).

Ez a magyarázat valamennyi korcsoport esetében megállja a helyét. Korábbi eredmények szerint a gyerekek 5-6 éves korukra rendelkeznek mindazokkal az arcészlelési képességekkel, amelyekkel a felnôttek. A holisztikus arcészlelés tekintetében a 4 éves gyerekek teljesítménye már nem különbözik a felnôttekétől (de Heering, Houthuys és Rossion, 2007; lásd még Carey és Diamond, 1994). Minôségi változás ez után az életkor után már nem történik, a kísérletek viszont azt mutatják, hogy az arcmemória és az egyedi arcok elkülönítésének képessége sokat javul kisiskoláskor és felnôttkor között. Az idegen arcok felismerési képessége 6 éves kortól a 10. életévig lineárisan növekszik, amit egy platófázis követ, majd 13 éves kortól ismét fokozatos fejlôdés figyelhetố meg 
(Lawrence, Bernstein, Pearson, Mandy, Campbell és Skuse, 2008). Az egyik magyarázat szerint ebben az idôszakban arcspecifikus észlelési folyamatok fejlődése játszódik le (Humphreys és Johnson, 2007; Johnston és Ellis, 1995; Nishimura, Maurer, Jeffery, Pellicano és Rhodes, 2008). Ezt támasztja alá, hogy az arcészlelésben szerepet játszó agyterületek (pl. fuziform tekervény) jelentôs méretbeli növekedésen esnek át felnôttkorig (Golarai és mtsai, 2007; Scherf, Behrmann, Humphreys és Luna, 2007). A másik elmélet azt hangsúlyozza, hogy az 5-6 éves korra már teljesen érett vizuális képességeken felül általános kognitív képességek, mint a koncentrációképesség, a vizuális figyelem és a memória további fejlốdése felelôs a gyerekek és a felnôttek teljesítménye közti különbségekért (Crookes és McKone, 2009).

Az ismeretlen személyek közti hasonlóság felismerésének képessége is fokozatosan alakul ki (Averett, Gennetian és Peters, 2000; Barrera és Maurer, 1981; de Schonen és Mathivet, 1990; Eibl-Eibesfeldt, 1989). A gyerekek nagyjából 5 éves kortól kezdve ismeretlen személyek közti rokonsági viszonyok felismerésére is képesek (Kaminski, Gentaz és Mazens, 2011), noha ennek hatékonysága még felnôttkorban sem százszázalékos (Kaminski, Dridi, Graff és Gentaz, 2009). A szülôii arcvonások detektálásának, illetve ezek preferenciájának hiányát magyarázhatja az általános és vizuális kognitív képességek fejlődésének idôbeli lefutása (Kocsor, 2017).

\section{Szülôvel való kapcsolat hatása az arcpreferenciákra}

A második hipotézisünkre vonatkozó eredményeink ugyanakkor azt mutatják, hogy a szülôkkel való kapcsolat minôsége befolyásolja az arcpreferenciák kialakulását. Ennek iránya azonban nem teljesen egyértelmú. Egyrészt a 10 év alatti korosztály eredményei arra utalnak - bár nem kaptunk szignifikáns modellt -, hogy a Düss-mesében a szülóket választó lányok a kontrollszemélyhez hasonló arcot nagyobb valószínúséggel választják az anyához hasonlóhoz képest, mint a fiúk. Az apai arc választásának valószínúségét ellenben, elsôsorban a fiúknak köszönhetôen, elôsegítette a szülôkkel való kapcsolat. A szüleiket nem választó gyermekek között az óvodások az alsósokhoz képest még inkább a kontrollt preferálták. A felsôsöknél kapott eredmények pedig arra utalnak, hogy az anyával való jó kapcsolat pozitívan befolyásolhatja az anyai arc iráni vonzódást, különösen a fiúknál.

A fenti eredményekhez tehát mindhárom tényezô, a nem, az életkor és a szülôvel való kapcsolat is hozzájárulhatott. Ezeket az összefüggéseket több tanulmány az ún. szexuális imprinting modell keretében értelmezi. Az elmélet szerint a gyerekek megtanulják szüleik fenotípusos sajátosságait, és ezt a modellt használják fel késôbbi, felnôttkori párválasztásukban. Hosszú távú kapcsolataikban olyan partnert választanak, aki hasonlít az ôket felnevelố szülőkhöz (és a genetikai rokonság miatt saját magukhoz is). Mint a bevezetôben utaltunk rá, a hasonlóságnak több elônye lehet, köztük a genetikai hasonlóság, illetve különbség optimalizációja (Thiessen és Gregg 1980, Bereczkei és mtsai, 2002, Wiszewska és mtsai, 2007; Marcinkowska, Moore és Rantala, 2013). Az alsós és óvodás lányok esetében kapott eredmények egybecsengenek ezen elméletek jóslataival és Saxton (2016) vizsgálatának eredményeivel is. Utóbbi azt találta, hogy a menarche utáni jó kapcsolat a szülôkkel növeli, az azt megelôzôen kapott nagyobb ér- 
zelmi támogatás viszont csökkenti a szülőkhöz hasonló partner iránt vonzódást. E kettôsség hozzájárulhat a genetikailag optimálisan különbözô partner kiválasztásához. Fiúknál nem figyelhetô meg ilyen életkori hatás. Ennek oka az lehet, hogy a gyermekvállalás költségei fốleg a nốknél jelentkeznek, ami számukra nagyobb szelekciós nyomást jelentett (Marcinkowska és mtsai, 2013; Rantala és Marcinkowska, 2011).

Fontos hangsúlyozni, hogy jelen vizsgálatunkban az azonos nemú átlagarcokba illesztettük a szülôk arcát. Elképzelhetô, hogy a felnôtt korosztály esetében megszokott ellentétes nemú arcba való illesztés módszerével eredményeink más színezetet mutatnának. Az alsós és óvodás korosztályban a kötôdési mintázat vizsgálata is problémás volt. Az általunk használt teszttel a finomabb különbségek nem mutathatók ki, az apához, illetve anyához jobban kötôdő gyerekek egyenlootlen eloszlása szintén korlátokat állított a pontosabb összefüggések feltárása elé. A jövôben mindenképpen érdemes lenne megvizsgálni más módszertani lehetôségeket is.

\section{KÖVETKEZTETÉSEK}

Lehetséges, hogy a 3-14 éves gyerekek szüleikkel való kapcsolatától függô arcpreferenciája ennek a szexuális imprintingnek az elsô megjelenési formája. Elképzelhetô tehát, hogy az ebben az idôszakban szerzett tapasztalataink befolyásolják, hogy késóbbi életünk során elônyben részesítjük különbözó választásainkban a szüleinkhez hasonlító embereket. Ugyanakkor ezek a hatások nehezen különíthetôk el az arcészlelés kognitív fejlődésének folyamataitól. Ennek az összefüggésnek a vizsgálata további kutatásokat igényel.

\section{KÖSZÖNETNYILVÁNÍTÁS}

A kutatást a Bolyai János Kutatási Ösztöndíj támogatta.

\section{IRODALOM}

Armsden, G. C., \& Greenberg, M. T. (1987). The inventory of parent and peer attachment: Individual differences and their relationship to psychological well-being in adolescence. Journal of Youth and Adolescence, 16(5),427-454.

Averett, S. L., Gennetian, L. A., \& Peters, H. E. (2000). Patterns and determinants of paternal child care during a child's first three years of life. Marriage $\mathcal{E}$ family review, 29, 115-136). Haworth Press. Retrieved from. Letöltve: 2015.12.03-án: http://cat.inist.fr/?aModele=afficheN\&cpsidt $=1162830$

Barrera, M. E., \& Maurer, D. (1981). Recognition of mother's photographed face by the three-month-old infant. Child Development, 52, 203-206.

Bateson, P. P. G. (1983). Optimal outbreeding. In P. P. G. Bateson (Ed.), Mate Choice (pp. 257-277).Cambridge: Cambridge University Press.

Bereczkei, T., Gyuris, P. and Weisfeld, G. E. (2004). Sexual imprinting in human mate choice. Proceedings of the Royal Society B: Biological Sciences, 271(1544), 1129-1134. 
Bereczkei, T., Gyuris, P., Koves, P. and Bernath, L. (2002). Homogamy, genetic similarity, and imprinting; parental influence on mate choice preferences. Personality and Individual Differences, 33(5), 677-690. doi:10.1016/S0191-8869(01)00182-9

Blouin, S. F., \& Blouin, M. (1988). Inbreeding avoidance behaviors. Trends in Ecology E̋ Evolution, 3(9), 230-233. https://doi.org/10.1016/0169-5347(88)90164-4

Carey, S., \& Diamond, R. (1994). Are faces perceived as configurations more by adults than by children? Visual Cognition, 1(2-3), 253-274. Letöltve: 2015.09.22-én: http://doi. org/10.1080/13506289408402302

Cassidy J., Shaver P. R. (Eds) (1999). Handbook of Attachement. Theory, Researche and Clinical Applications. London, New York: The Guilford Press.

Crookes, K., \& McKone, E. (2009). Early maturity of face recognition: no childhood development of holistic processing, novel face encoding, or face-space. Cognition, 111(2), 219-247. Letöltve: 2009.02.04-én: http://doi.org/10.1016/j.cognition.

de Heering, A., Houthuys, S., \& Rossion, B. (2007). Holistic face processing is mature at 4 years of age: Evidence from the composite face effect. Journal of Experimental Child Psychology, 96(1), 57-70.

de Schonen, S., \& Mathivet, E. (1990). Hemispheric asymmetry in a face discrimination task in infants. Child Development, 61(4), 1192-1205. Letöltve: 2016.01.12-én: http://doi. org/10.1111/j.1467-8624.1990.tb02853.x

DeBruine, L. M., Jones, B. C., Little, A. C., \& Perrett, D. I. (2008). Social perception of facial resemblance in humans. Archives of Sexual Behavior, 37(1), 64-77. https://doi.org/10.1007/ s10508-007-9266-0

Eibl-Eibesfeldt, I. (1989). Human Ethology. New York: Berghahn.

Fraley, R. C. and Marks, M. J. (2010). Westermarck, Freud, and the Incest Taboo: Does familial resemblance activate sexual attraction? Personality and Social Psychology Bulletin, 36(9),1202-1212. Letöltve: 2015.09.27-én: doi:10.1177/0146167210377180

Golarai, G., Ghahremani, D. G., Whitfield-Gabrieli, S., Reiss, A., Eberhardt, J. L., Gabrieli, J. D. E., \& Grill-Spector, K. (2007). Differential development of high-level visual cortex correlates with category-specific recognition memory. Nature Neuroscience, 10(4), 512-522. Letöltve: 2016.03.08-án:http://doi.org/10.1038/nn1865

Hamilton, W. D. (1964). The genetical evolution of social behaviour. Journal of Theoretical Biology, $7(1), 1-52$.

Heffernan, M. E., \& Chris Fraley, R. (2013). Do early caregiving experiences shape what people find attractive in adulthood? Evidence from a study on parental age. Journal of Research in Personality, 47(4), 364-368. http://doi.org/10.1016/j.jrp.2013.03.003

Humphreys, K., \& Johnson, M. H. (2007). The development of „face-space” in infancy. Visual Cognition, 15(5), 578-598. http://doi.org/10.1080/13506280600943518

Jedlicka, D. (1980). A test of the psichoanalitic theory of mate selection. Journal of Social Psichology, 112, 295-299.

Jedlicka, D. (1984). Indirect parental influence on mate choice: a test of the psychoanalytic theory. Journal of Marriage and Family, 46(1),65-70.

Johnston, R. A., \& Ellis, H. D. (1995). Age effects in the processing of typical and distinctive faces. Quarterly Journal of Experimental Psychology Section A: Human Experimental Psychology, $48(2), 447-465$.

Kaminski, G., Dridi, S., Graff, C., \& Gentaz, E. (2009). Human ability to detect kinship in strangers' faces: effects of the degree of relatedness. Proceedings of the Royal Society B: Biological Sciences, 276(1670), 3193-3200. Letöltve: 2014.03.12-én: http://doi.org/10.1098/ rspb.2009.0677 
Kaminski, G., Gentaz, E., \& Mazens, K. (2011). Development of children's ability to detect kinship through facial resemblance. Animal Cognition, 15(3), 421-427. http://doi.org/10.1007/ s10071-011-0461-y

Kocsor F. (2017). A hasonlóságdetekció kognitív érési folyamatai gyerekkorban. In Bóna A., Lénárd K., \& Pohárnok M. (szerk.), Bontakozó jelentés: Tanulmányok a 60 éves Péley Bernadette köszöntésére (pp. 119-126). Budapest: Oriold és Társai Kiadó.

Kocsor, F., Gyuris, P., \& Bereczkei, T. (2013). The impact of attachment on preschool children's preference for parent-resembling faces - A possible link to sexual imprinting. Journal of Evolutionary Psychology, 11(4), 171-183. https://doi.org/10.1556/JEP.11.2013.4.2

Kocsor, F., Rezneki, R., Juhász, S., \& Bereczkei, T. (2011). Preference for facial self-resemblance and attractiveness in human mate choice. Archives of Sexual Behavior, 40(6), 1263-1270. https://doi.org/10.1007/s10508-010-9723-z

Kocsor, F., Saxton, T. K., Láng, A., \& Bereczkei, T. (2016). Preference for faces resembling opposite-sex parents is moderated by emotional closeness in childhood. Personality and Individual Differences, 96, 23-27. https://doi.org/10.1016/j.paid.2016.02.065

Kôvári, Z. \& Látos, M. (2010). „Nem segíthet rajta, csak a pszichológus...” Pszichoanalitikus állatmese a színvásznon. Thalassa, 21(1), 71-76.

Lawrence, K., Bernstein, D., Pearson, R., Mandy, W., Campbell, R., \& Skuse, D. (2008). Changing abilities in recognition of unfamiliar face photographs through childhood and adolescence: performance on a test of non-verbal immediate memory (Warrington RMF) from 6 to 16 years. Journal of Neuropsychology, 2(Pt 1), 27-45.

Little, A. C., Penton-Voak, I. S., Burt, D. M., \& Perrett, D. I. (2002). Investigating an imprinting-like phenomenon in humans. Partners and opposite-sex parents have similar hair and eye colour. Evolution Human Behaviour, 24, 43-51.

Marcinkowska, U. M., \& Rantala, M. J. (2012). Sexual imprinting on facial traits of opposite sex parents in humans. Evolutionary Psychology. http://www.epjournal.net/articles/sexualimprinting- on-facial-traits-of-opposite-sex-parents-in-humans/

Marcinkowska, U. M., Moore, F. R., \& Rantala, M. J. (2013). An experimental test of the Westermarck effect: sex differences in inbreeding avoidance. Behavioral Ecology, art028. Letöltve: 2015.11.21-én: http://doi.org/10.1093/beheco/art028

Mazzeschi, C., Lis, A., Calvo, V., Vallone, V., \& Superchi, E. (2001). Düss fairy tales: some data from a new evaluation form. Perceptual and Motor Skills, 93(3), 806-812.

Nishimura, M., Maurer, D., Jeffery, L., Pellicano, E., \& Rhodes, G. (2008). Fitting the child's mind to the world: Adaptive norm-based coding of facial identity in 8-year-olds. Developmental Science, 11(4), 620-627. http://doi.org/10.1111/j.1467-7687.2008.00706.x

Nojo, S., Ihara, Y., Furusawa, H., Akamatsu, S., \& Ishida, T. (2011). Facial resemblance and attractiveness: an experimental study in rural Indonesia. Letters on Evolutionary Behavioral Science, 2(1), 9-12. Letöltve: 2015.02.21-én: http://doi.org/10.5178/lebs.2011.11

Nojo, S., Tamura, S., \& Ihara, Y. (2012). Human homogamy in facial characteristics. Human Nature, 23(3), 323-340. Letöltve: 2015.02.21-én http://doi.org/10.1007/s12110-012-9146-8

Perrett, D., Penton-Voak, I. S., Little, A. C., Tiddeman, B. P., Burt, D. M., Schmidt, N. et al. (2002). Facial attractiveness judgments reflect learning of parental age characteristics. Proceedings of the Royal Society of London. Series B: Biological Sciences, 269(1494), 873-880. Letöltve: 2015.02.21-én: doi:10.1098/rspb.2002.1971

Potts, W. K., Manning, C. J., \& Wakeland, E. K. (1991). Mating patterns in seminatural populations of mice influenced by MHC genotype. Nature, 352(6336), 619-621. https://doi. org/10.1038/352619a0

Rantala, M. J., Pölkki M., \& Rantala L. M.(2009). Preference for human male body hair changes across the menstrual cycle and menopause. Behavioral Ecology, 21(2), 419-423. 
Rantala, M. J., \& Marcinkowska, U. M. (2011). The role of sexual imprinting and the Westermarck effect in mate choice in humans. Behavioral Ecology and Sociobiology, 65(5), 859-873. Letöltve: 2015.04.21-én: http://doi.org/10.1007/s00265-011-1145-y

Read, A. F., \& Harvey, P. H. (1988). Genetic relatedness and the evolution of animal mating patterns. In C. G. N. Mascie-Taylor \& A. J. Boyce (Eds.), Human Mating Patterns (pp. 115-131). Cambridge: Cambridge University Press.

Reynolds, C. R., \& Kamphaus, R. W. (Eds) (2003). Handbook of Psychological and Educational Assessment of Children, 2/e: Intelligence, Aptitude, and Achievement. Guilford Press.

Richter, N., Tiddeman, B., \& Haun, D. (2012). Preschooler's perception and use of self-similarity in others. Poszter presented at the 7th Conference of the European Human Behavior and Evolution Association, Durham, UK.

Saxton, T. K. (2016). Experiences during specific developmental stages influence face preferences. Evolution and Human Behavior, 37(1), 21-28. Letöltve: 2014.11.21-én: http://doi. org/10.1016/j.evolhumbehav.2015.06.001

Scherf, K. S., Behrmann, M., Humphreys, K., \& Luna, B. (2007). Visual category-selectivity for faces, places and objects emerges along different developmental trajectories. Developmental Science, 10(4), F15-F30. Letöltve: 2016.02.12-én: http://doi.org/10.1111/j.1467-7687.2007. 00595.x

Seki, M., Ihara, Y., \& Aoki, K. (2012). Homogamy and imprinting-like effect on mate choice preference for body height in the current Japanese population. Annals of Human Biology, 39(1), 28-35.

Sulutvedt, U., \& Laeng, B. (2014). The self prefers itself? Self-referential versus parental standards in face attractiveness. PeerJ, 2, e595. Letöltve: 2016.03.04-én: http://doi.org/10.7717/ peerj. 595

Thiessen, D., \& Gregg, B. (1980). Human assortative mating and genetic equilibrium: an evolutionary perspective. Ethology and Sociobiology, 1, 111-140.

Tiddeman, B. P., Stirrat, M. R., \& Perrett, D. I. (2005). Towards realism in facial image transformation: Results of a wavelet MRF method. Computer Graphics Forum, 24(3), 449-456. Letöltve: 2015.07.21-én doi:10.1111/j.1467-8659.2005.00870.x

Tiddeman, B., Burt, M., \& Perrett, D. (2001). Prototyping and transforming facial textures for perception research. IEEE Computer Graphics and Application, 21(5), 42-50. Letöltve: 2016.05.21-én: doi:10.1109/38.946630

Vukovic, J., Boothroyd, L. G., Meins, E., \& Burt, D. M. (2015). Concurrent parent-child relationship quality is associated with an imprinting-like effect in children's facial preferences. Evolution and Human Behavior, 36(4), 331-336. Letöltve: 2016.03.04-én: http://doi. org/10.1016/j.evolhumbehav.2015.03.004

Watkins, C. D., DeBruine, L. M., Smith, F. G., Jones, B. C., Vukovic, J., \& Fraccaro, P. (2011). Like father, like self: emotional closeness to father predicts women's preferences for self-resemblance in opposite-sex faces. Evolution and Human Behavior, 32(1), 70-75. http://doi. org/10.1016/j.evolhumbehav.2010.09.001

Wilson, D.S. \& Barrett, P.T. (1987). Parental characteristic and partner choice: Some evidence for Oedipal imprinting. Journal of Biosocial Science, 19, 157-161.

Wiszewska, A., Pawlowski, B., \& Boothroyd, L. (2007). Father-daughter relationship as a moderator of sexual imprinting: A facialmetric study. Evolution and Human Behavior, 28(4), 248-252. Letöltve: 2014.05.03-án: doi:10.1016/j.evolhumbehav.2007.02.006

Zei, G., Astofli, P., \& Jaykar, S. D. (1981). Correlation between father's age and husband's age: A case of imprinting? Journal of Biosocial Science, 13, 409-418. 


\title{
PARENTAL BONDING, FACE PREFERENCES IN CHILDHOOD, AND SEXUAL IMPRINTING
}

\author{
GYURIS, PETRA - KOCSOR, FERENC - BERECZKEI, TAMÁS
}

Background and objectives: In the last years several research reports have been published which studied the effect of parental appearance on the social preferences of adults. The current study aims at investigating whether parental models are used by children in their social relations.

Methods: In our study we used a computer software to manipulate composite faces so as to resemble the parents of the participating children (between 3 and 14 years). The images were arranged into pairs and the children were asked to choose the one they find more attractive from each pair. The children's relation with their parents was assessed with the Düss-tale test and the IPPA questionnaire.

Results: In the age group of the 11-14 years old children we found that high scores on the maternal alienation subscale (i. e., good relation with the mother) increased the likelihood of choosing a peer resembling the participant's mother. That was particularly true for boys. Similarly, in the group of boys between 3-6, and 7-10 years, good relation with the mother increased the chance of prefering a mother-resembling face to controls. In contrast, in this age group good parental relation decreased girls preference for maternal faces.

Conclusions: These results suggest that experiences in childhood affect children's face preferences, which may be maintained in adulthood, too, influencing interpersonal decisions. This may manifest, for instance, in a bias for parent-resembling people in various social relations, such as mate-choice. We assume that evolutionary causes stand in the background, but the differences we found in our study between the age groups indicate that constraints of cognitive maturation might also crucially contribute to the development of these preferences.

Keywords: children's faces, face preference, family environment, mate choice, sexual imprinting 